\title{
Empirical Study on the Effectiveness of College English Teaching Based on Smart Phone Application
}

\author{
Liu Weiwei \\ Basic Teaching Department, Shandong Huayu University of Technology, Dezhou, Shandong, China 253034 \\ 673559273@qq.com
}

Keywords: smart phone, College English, classroom teaching, empirical research

\begin{abstract}
In view of the fact that the teaching content of college English teaching is relatively old, the interaction between teachers and students is less, the students' ability of autonomous learning is not strong and the ability of language application is poor, it is necessary to improve the teacher's traditional single classroom teaching model, to establish a student-centered teaching philosophy and to make full use of a variety of information technology tools so that English teaching can be developed for students of the employment environment, and classroom teaching can be developed in the direction of application. Meanwhile students can fully demonstrate the personality and autonomy in the English classroom learning. Based on the combination of theoretical analysis and empirical analysis, this paper studies the specific situation of classroom teaching based on smart phone in business English major of applied undergraduate university.
\end{abstract}

\section{Introduction}

The rapid development of modern information technology, especially modern communication technology, has brought great convenience to people's daily production, learning and life. The emergence of smart phones has caused great changes in people's learning and life. For college students, the range and extent of smart phone applications is extremely high. Therefore, if the smart phone can be effectively applied to the English classroom teaching activities, it is undoubtedly a major innovation and attempt of English classroom teaching. The characteristics and functions of the smart phone itself make it not only a new type of teaching method in the teaching of college English classrooms, but also can fully utilize the powerful web application and interactive functions of smart phones, greatly enrich the students' English learning materials and stimulate students' interest in learning to build a student-centered classroom teaching model that helps students reinforce their understanding of classroom content. In addition, the application of smart phones can also break the limitations of students' English learning and achieve effective integration in multi-dimensional time, space and various learning resources. This paper explores the effectiveness of smart phones in college English classroom teaching through literature analysis, survey analysis, comparative analysis, etc. How to promote learning collaboration and interaction in college English classroom teaching in the context of smart phones, in order to improve the effectiveness of college English classroom teaching based on smart phone applications?

\section{Literature Review}

\subsection{Relevant theory of information teaching in smart phone classroom}

The informationization of smart phone English classroom teaching refers to the introduction of intelligent modern mobile communication tools into English classroom teaching. Through the visualization of English teaching content, the purpose of English classroom teaching is improved. Therefore, English teachers need to change the stereotyped and mechanical way of traditional English classroom teaching. By introducing smart phones, building virtual classrooms, establishing a smart learning environment, promoting the deep integration of information technology and English teaching, and utilizing the intuitiveness and interaction of smart phones can fully mobilize 
the interest and enthusiasm of students' English learning, and effectively promote the improvement of learning English learning.

As early as 2000, the UK Education Communication and Technology Agency investigated the application of information and communication technology in teaching. The agency conducted a survey of 2,110 schools and found that among schools with good information resources, up to $77 \%$ of students have achieved the required level of study, which indicates the important role of information resources in education informationization.

\subsection{Smart phone Assisted Instruction Multimodal Theory}

Chinese scholar Gu Yuguo (2007) gives the concept of "modality". He thinks that" modality" refers to the way humans interact with each other through the senses such as sight and hearing. It is generally believed that interaction with three or more senses is a multi-modal interaction. In fact, as early as 1996, New London Group proposed a multi-modal teaching method that uses multiple symbolic resources such as sound, moving images, still images, and body movements to be more effective by mobilizing multiple senses, which achieves better teaching results. With the rapid development of modern information technologies such as the Internet and smart phones, introducing them into the teaching environment can make the types of multi-modal resources more abundant, which is more conducive to the improvement of teaching effects.

\section{Research Design}

\subsection{Research object}

The research object of this paper is 135 students from the three classes of non-English majors in our school. The questionnaire survey is used to study the teaching situation of their smart phones used in English classes.

\subsection{Research methods}

\subsubsection{Investigation and Research Method}

Through the design of questionnaires, the relevant research subjects - the relevant professional class students of applied undergraduate university will conduct a questionnaire survey, analyse the basic situation of their application of smart phones for English classroom teaching, and understand the application of smart phones to teachers and students, and the effect of English classroom teaching.

\subsubsection{Empirical Analysis}

Using the method of empirical analysis, the reliability and validity of the questionnaire and relevant survey content is analysed, and then the basic principles of statistics are further applied to the attitudes, preferences and effects of teachers and students for classroom teaching. And methods for empirical analysis are taken to make the analysis of the problem deeper, get more useful information, and provide strategic guidance for further improving the effectiveness of English classroom teaching.

\section{Data Collection}

This study obtained data through questionnaires. 135 students from 3 classes of our 2016 non-English majors were selected as test subjects. 120 students from the other 3 classes were selected as comparison objects. A total of 255 questionnaires were distributed and 240 questionnaires were collected. The questionnaire recovery rate was 94.12 . \%, of which 230 valid questionnaires, the effective rate of the questionnaire is $95.84 \%$. The duration of the experiment is 5 months, that is, one semester.

The questionnaire is divided into three parts. Part A is the use of smart phones as general media usage habits, Part B is the behaviour and attitude of respondents using smart phones as English 
classrooms, and Part $\mathrm{C}$ is the basic information of participants, such as gender, grade, college entrance examination English scores, contact information, etc. Among them, Part A is used to investigate the purpose of respondents using smart phones as a general medium, and Part B's B2-B15 questions are used to investigate the behaviours and attitudes of respondents using smart phones in English classroom learning.

The questionnaire was designed mainly using the Likert scale, and the respondents were asked to answer with an integer between 1 and 5, with 1 being the most disagree and 5 being the most agreeable.

The three factors extracted from the factor analysis of A1-A5 were analysed for reliability, $\alpha=0.831$, and the Alpha coefficient after deleting each item was between 0.811 and 0.828 , which showed little change, indicating the internal consistency of the five questions is better. The reliability analysis was performed on the five factors, and the results are shown in Table 1.

Table 1 Reliability coefficient of social application use attitude coefficient

\begin{tabular}{|c|c|c|c|}
\hline Factor & 1 & 2 & 3 \\
\hline Reliability coefficient & 0.794 & 0.742 & 0.755 \\
\hline
\end{tabular}

It can be seen from Table 1 that the reliability coefficients of the three factors are all greater than 0.7 , and the internal consistency is better.

The five factors extracted from B6-B22 were analysed for reliability analysis, $\alpha=0.836$, and the Alpha coefficient after deleting each item was between 0.820 and 0.844 , with little change, indicating the internal consistency of the 17 questions is better. The reliability analysis was performed on the five factors, and the results are shown in Table 2.

Table 2 English learning behavior and attitude coefficient of each factor

\begin{tabular}{|c|c|c|c|c|c|}
\hline Factor & 1 & 2 & 3 & 4 & 5 \\
\hline Reliability coefficient & 0.871 & 0.787 & 0.715 & 0.763 & 0.742 \\
\hline
\end{tabular}

As can be seen from Table 2, the reliability coefficients of the five factors are all greater than 0.7 , and the internal consistency is better. The statistical test results of the survey scales used by the 2016 non-English majors in the classroom for classroom teaching indicate that the scale design has good structural validity.

\section{Data Analysis}

\subsection{Students' general understanding of English-based classroom teaching based on smart phones}

When investigating the use of smart phones for English classroom learning, most of the tested objects indicated that the use of smart phones for English classroom teaching is relatively new, and students prefer it, with up to $64.3 \%$ of students accepting attitudes; The attitude of the smart phone in teaching English is correct. $41.2 \%$ of the students said that the attitude of learning English in the classroom is correct. The lectures in class are more serious than before. For the use of smart phones for English classroom teaching, students are actively involved with teachers or classroom interaction between classmates, 38.9\% of students expressed active participation in classroom interaction with teachers or classmates.

After using the smart phone for English classroom teaching, the testees generally indicated that all aspects of English have improved: $14.6 \%$ of the respondents indicated that their English listening skills were improved, and $31.2 \%$ of the testees indicated that they adopted intelligence. Mobile phones are taught in English classrooms, with more opportunities for interaction and a certain improvement in verbal expression. $28.2 \%$ of the respondents indicated that their reading ability has improved, $14.5 \%$ of the respondents indicated that their writing ability has improved, and $11.5 \%$ of them have been tested. And the comprehensive ability has been improved. 


\subsection{Preferences for English teaching content with different expressions}

The survey shows that after using the smart phone for English classroom teaching, students have different preferences for English teaching content with different expressions. For the teaching content presented on the mobile phone by text, $18.6 \%$ of the respondents indicated that they prefer to the teaching content presented on the mobile phone by text; for the teaching content presented on the mobile phone in audio form is preferred, $24.9 \%$ of the testees express preference for teaching content expressed in audio form; for the teaching content presented above is preferred, $45.3 \%$ of the respondents expressed preference for teaching content presented in video form; for the teaching content presented on the mobile phone in an animated form, $12.2 \%$ of the tested persons expressed preference for animated teaching content.

\section{Results and Discussion}

\subsection{Student evaluation}

First, the participation of students in English classroom learning is improved. Because the tools that are generally preferred by students such as smartphones are applied to classroom teaching in English, students' enthusiasm for English learning is higher, and the degree of participation in learning is much higher than that of traditional model teaching. The specific performance is that students like to use familiar smart phones for basic operations and proficient in searching for questions and answers. Students like to use smart phones to conduct classroom exercises through English-specific software. Students like to use smart phones to interact with teachers or other students to learn in English class discussion activities and so on.

Second, it stimulated the interest in English learning. According to the survey results, 56.4\% of the students believe that the application of smart phones to English classroom teaching greatly stimulates the interest in learning English. 32.5\% of the students think that they can concentrate on English when using smart phones, while only $16.8 \%$ of students think that it is easy to cause distraction. These students think that learning content is the main factor that determines the attention and learning effect. 51.6\% of the students believe that the introduction of smart phones into English classroom teaching can effectively improve the efficiency of English learning and a positive attitude towards mobile learning.

Finally, the basic skills of students in English have been improved. Advanced media technology is more important to improve the ability of listening, speaking, reading, writing and translating English. Smart phones, because of their comprehensiveness of functions, have a role in helping to improve the basic skills of English. Many students believe that smart phones can create a good language learning environment for students, and they have great flexibility. With the advanced media technology of smart phones, students can create an immersive language environment and learn English. Especially in listening and speaking, the students' interest in learning English is greatly enhanced, and the basic skills in all aspects of English have been improved.

\subsection{Teacher's evaluation of smart phone science applications}

In carrying out English classroom teaching using smart phone mobile terminal, students' learning interest and learning initiative are obviously improved, classroom participation is also improved, teachers' teaching work becomes relatively easy, and teaching is more devoted; The ability requirements for teaching to teachers are higher. Teachers should not only carefully prepare the teaching content, but also try to cope with the various problems raised by students from various angles and aspects. Moreover, they need to improve the various operational capabilities of mobile devices, and each lesson should fully conceive the whole process. In the teaching process, it is required to strive to achieve effective results in each teaching session; students shall learn more English knowledge and skills, and through learning and interaction, and the relationship between teachers and students shall be further close, so that this relationship is more harmonious and intimate, which helps students to establish a group spirit of friendship and mutual assistance. 


\section{Conclusion}

This paper uses theoretical analysis and empirical analysis to study the specific situation of the 2016 non-English major based on smart phone classroom teaching. The study found that smart phones have greatly improved and enhanced the effectiveness of college English classroom teaching. From the teacher level, it changed Herbart's pedagogy thoughts, changed the teaching mode of teacher-led and passive acceptance of English classroom teaching, changed the traditional teaching methods and methods of teachers, also greatly benefited teachers, and continuously updated knowledge; from the student level, the introduction of smart phones into English classroom teaching has transformed students' traditional learning methods, enabling students to transform from traditional passive learning to active learning. At the same time, learning can be guided to constantly accepting knowledge and constantly improving the learning ability on the track. In short, the application of smart phones to English classroom teaching can make English classrooms become the "dual subject" classroom for teachers and students. The "interactive learning" between teachers and students has become the new classroom teaching mode of college English for information education.

\section{Acknowledgements}

This work was supported by the projects of vocational education teaching reform research project in Shandong Province in 2017(Project Code: 2017306) and education science planning project in Shandong Province in 2017. (Project Code:BYGW2017001)

\section{References}

[1] China Internet Network Information Center. The 37th Statistical Report on the Development of China's Internet Network[DB/OL]. http://tech.sina.com.cn/i/2016-01-22/doc -ifxnuvxh5088776.shtml,2016-1-22.

[2] Stockwell, G. Using mobile phones for vocabularyactivities: examining the effect of the platform [J]. Language Learning \& Technology, 2010, 14(2): 95-110.

[3] Tindell, D. R., \& Bohlander, R. W. The use andabuse of cell phones and text messaging in the classroom: a survey of college students [J]. College Teaching, 2012, 60(1): 1-9.

[4] Wu, W., etc. Review of Trends from Mobile Learning Studies: A Meta-Analysis. Computers \& Education [J]. Computers \& Education, 2012, 59(2): 817-827.

[5] Kim, H. Effects of SMS Text Messaging on Vocabulary Learning [J]. Multimedia -Assisted Language Learning, 2011, 14(2): 159-180.

[6] Hwang, W-Y., Chen, C-Y., \& Chen, H. Facilitating EFL writing of elementary school students in familiar situated contexts with mobile devices [A]. Proceedings of 10th World Conference on Mobile and Contextual Learning [C]. Beijing: Beijing Normal University Press, 2011, 15 -23.

[7] Jiang Qiang, Zhao Wei, Wang Pengjiao. Study on the Cognition of College Students' Mobile Learning Based on Smartphone in the Perspective of Fragmented Learning[J]. Modern Distance Education.2014, (1): 37-42.

[8] Munoz -Organero, M., Munoz -Merino, J. P., Kloos, D. C. Sending Learning Pills to Mobile Devices in Class to Enhance Student Performance and Motivation in Network Services Configuration Courses [J]. IEEE Transactions on Education, 2012, 55(1): 83-87.

[9] Uluyol, C., Agca, K. R. Integrating Mobile Multimedia into Textbooks: 2D Barcodes [J]. Computers \& Education, 2012, 4(59): 1192-1198.

[10] Jia Jiyou, Klaus Mainzell. Using natural language human-computer interaction technology to create English conversation context [J]. China Electro-education Education. 2006, (10): 87-91. [23] 
Jia, J. etc. Effects of an intelligent web -based English instruction system on students'academic performance [J]. Journal of Computer Assisted Learning. 2013,29(6):556-568.

[11] Jia, J. Intelligent Web -Based English Instruction in Middle Schools [M]. PA: IGI Global, 2014.

[12] Li thickened. The technology that ultimately changes the classroom may be a mobile phone [J]. China Information Technology Education, 2015, (10).

[13] Guo Xiaoqi. Research on the application of mobile learning based on smartphone in English teaching [D]. Shenyang Normal University, 2014.

[14] Jiang Wei, Fei Hongxiao, Ling Ruixuan. Research on university wisdom classroom based on mobile internet [J]. China Education Informatization, 2016, (01).

[15] He Kekang. From the essence of "flip classroom", look at the future development of "flip classroom" in China [J]. Research in Audio-Visual Education, 2014, (07). 